\title{
Analysis on Modern Anomie Situation of Chinese Traditional Festivals
}

\author{
Jinxia Wang ${ }^{1}$, Xiaoqing Tang ${ }^{2}$, Yali Pang ${ }^{3} \&$ Wenjie Duan ${ }^{2}$ \\ ${ }^{1}$ Cultural Development Research Institute of Chongqing, Chongqing, China \\ ${ }^{2}$ Department of Applied Social Studies, City University of Hong Kong, Hong Kong \\ ${ }^{3}$ L. Douglas Wilder School of Government and Public Affairs, Virginia Commonwealth University, Richmond, \\ VA, USA \\ Correspondence: Xiaoqing Tang, Department of Applied Social Studies, City University of Hong Kong, Tat \\ Chee Avenue, Kowloon, Hong Kong SAR. Tel: 85-2-3442-3747. E-mail: xqtang@cityu.edu.hk
}

Received: February 22, 2014 Accepted: March 26, 2014 Online Published: June 4, 2014

doi:10.5539/ach.v6n2p56

URL: http://dx.doi.org/10.5539/ach.v6n2p56

\begin{abstract}
Facing tremendous social changes in modern times, Chinese traditional festival as an important carrier of Chinese traditional culture, is encountering unprecedented development plights and survival crisis. In recent years, with the general concerns and widespread attention from the Chinese government and all sectors of the society, the traditional festivals have shown gradual revival from the declining trend. However, it should be noted that lack of core modern values, loss of emotional experience identity, missing of traditional folk arts, mess of the application of festival symbols, and popularity of western festivals culture are important representations of the anomie situation of Chinese traditional festivals in modern society, and also the crucial reason for it failed to overcome the difficulties. Globalization and the rapid development of information technology, the advancement of industrialization and urbanization have changed the social structure and people's lifestyles, rhythm, and also interpersonal relationships to a considerable extent, thus social environment for the survival of the traditional festivals related to agricultural society increasingly becomes narrow, and its impact and charm naturally bleak. Therefore, it is imperative to re-understanding and reconstructing traditional festivals, with new representations to restore the cultural connotations of traditional festivals, making it back into ordinary people's lives.
\end{abstract}

Keywords: Chinese traditional festivals, cultural values, folk arts, national identity, reconstructing

\section{Introduction}

Anomie is a sociological term, put forward by the famous French sociologist Emile Durkheim in the "The Division of Labor in Society". Anomie is the antithesis of morality, mainly refers to the dramatic social changes, the inapplicability of the traditional cultural values to the social norms, while new social norms had yet been established, or the functions of some social norms have been destroyed or obstructed, leading to loss of value norms to guide human behaviors, and down to the disorder (Durkheim, 2000). Seven major Chinese tradition festivals are respectively Spring Festival, Lantern Festival, Tomb Sweeping Festival, Dragon Boat Festival, Qixi Day, Mid-Autumn Festival, Double Ninth Day, and nowadays people still spend the holidays, but mostly they are just superficial, only a few cultural symbols like festival souvenir, festivals food and festive entertainments which can bring about economic benefits can get some attention in the social environment dominated by consumption market, whereas the profound inherent spirits, emotions and cultural connotations are often intentionally or unintentionally ignored. Obviously, this situation Chinese traditional festivals facing is in a kind of "anomie" of cultural dilemma, mainly for lack of core modern values, loss of emotional experience identity, missing of traditional folk arts, mess of the application of festival symbols, and popularity of western festival culture.

\section{Lack of Core Cultural Values of Modern Time}

For any one nation, "traditional festivals play crucial role in enhancing cohesion, establishing core values, and strengthen cultural identity" (2011). However, the current Chinese traditional festivals do not very well to play its role in establishing the core values of modern time, mainly there are three aspects. 
First of all, gradually weakening spiritual connotation in the festivals. Chinese traditional festivals are the product of the ancient agricultural civilization, losing its soil of farming culture in modern society, the unique spiritual connotations embedded in it are also increasingly weakened, and nowadays it has been difficult to highlight the festive spirit and cultural charm of traditional festivals.

As the folklorists Mr. Feng Jicai pointed out: "The traditional festival is the climax of life, is the carrier of comprehensive and ultimate values of the nation, is the most distinctive and focused representation of the DNA of one people, but also a national collective cultural creation. However, Chinese traditional festival spirits are obsolete, which is a harsh fact" (Feng, 2009). In other words, the spirit of the traditional festivals do not very well integrated into modern society. For example, patriotism is one of the important cultural symbol of Chinese traditional festivals, especially best embodied in the Dragon Boat Festival, which has the long history from the legend of Qu Yuan gradually formed a patriotism for concern about one's country and people as the core of the spiritual and cultural connotations. Since ancient times, Chinese people expressed not only the mourning and respect for Qu Yuan, but also the patriotic spirit of the Chinese nation for celebrating the festival, while now rice pudding (Zong zi) is just a symbol of the food on Dragon Boat Festival, dragon boat racing is no longer exclusive to the Dragon Boat Festival but also becomes a usual event, losing its original culture connotation, and promoting patriotism is no longer worthy of the old name.

There is also an important related reason for the weakening of the festival spirit, which is the overemphasis of developing external forms. For example on the Tomb Sweeping Festival, which carries the spirit of filial piety, the sacrifice has become the comparison of the luxurious rituals or oblations, overspent in renovating the ancestral graves, and the embedded cultural connotations facing the challenge from modern civilization. In Mid-Autumn Festival, full of meaning of reunion and harmony, moon cake is originally an ordinary festival food, while now there is a tendency to concern about the forms, with extravagant package, such as the precious sandalwood box or jade box. More incredible is the jewelry moon cakes which were made of real gold or silver, stuffing with various expensive food material like trepan or abalone. As one professor of NanKai University said, "this current traditional cultural heritage (Mid-autumn Festival) has shown a fracture, more moon cakes are sent out, while its soul had disappeared" (Liu, 2007). What must be noted is that the traditional Chinese festival is an important carrier of the spirit of traditional Chinese national culture and ethos, the wane of its meaning will be a great loss of the cultural wealths.

Besides, the worldview of unity of heaven and man has been challenged. For Chinese ancient people, the universe and the human being are unified and harmoniously coexist, and people follow the festivals, approaching and coordinating with the nature. With the transition into modern civilization and the orientation for multiculturalism and heterogenization in culture, this worldview is questioned by more and more people. As some scholars have pointed out that this spirit of thinking is going to be sealed up by big machine production of industrial society and the digital production in post-industrial society, and this era of transition, is constantly challenging the traditional festivals (Feng, 2009). This can be analyzed from natural culture and human relations perspectives. From the perspective of natural culture, the worldview of the unity of heaven and men in Chinese traditional festivals explain the relationship between the human-being and the nature in the customs or rituals, such as excursion or picnic in Tomb Sweeping Festival, watching moon on the Mid-autumn Festival evening, climbing mountains on Double Ninths Day, all these are representations of communication and harmonious relationship between the men and the nature (Feng, 2009). However, fast-paced lifestyle in modern industrial and urban society poses a great challenge to these heritages, because many people would like to take advantage of holidays to rest at home in order to relieve the stress of work and life, causing it difficult to experience that respect for nature and the emotion or perception for harmonious relationship with the natural culture. People pay attention to holiday diet habits, which embodies the periodically enjoyment and fulfillment between festivals and the nature, but also "a special expression for Chinese people dealing with the relationship between heaven and human society" (Liu et al., 2005). However, the festival diet customs have changed in modern culture for many people, more commercial meanings are inserted, like what we have discussed before, the moon cake in Mid-autumn Festival connected with the reunion meaning has become some upscale gift, symbolism of both wax of moon and the reunion of family have been watered down. Obviously, aspects of harmonious festival material life thought is suffering from the impact of modern life, and gradually losing the role of festivals in promoting the connection between the men and the nature.

From the perspective of ethical value of human relations, national traditional festivals focus more on the ethics of relations and interpersonal harmony among people. Many festivals share the common characteristics of kinship and ethics, such as reunion in Chinese New Year, excursion and sweeping tomb for worshiping the ancients in Tomb Sweeping Festival, etc. expressing a profound ethical and cultural significance (Yu, 2012). 
However, nowadays people are always busy with a variety of festive holiday dinner entertainments, or transfer message just by internet or other information technology facilities on holidays, losing the authentic meaning of its value.

In addition, every time one of the Chinese traditional festivals is approaching, the concerned divisions like media or propaganda department are inclining to advocate a scientific and civilized holiday idea, but often ignore the sense of ritual and awe for these festivals. Therefore, people do not take holidays as an important issue but things unnecessary, so as not to participate actively or sincerely, will not be able to feel the cultural connotation of the unity and harmony of heaven and men from the festival rituals, not even with spiritual purification and state enhancement.

Last but not the least, the concept of people-oriented festival needs to be strengthened. A famous Chinese philosopher Mr. Li Zehou said: "Chinese culture is secular, emphasizing humanity and human happiness" (Li, 2008). Based on this, human being is the main body in Chinese traditional festivals, the festival contents dedicate to meeting the various needs of people, for instance, the Spring Festival and Mid-Autumn Festival are for people's family reunion, and nourishing hope and the pursuit of affection, the Tomb Sweeping Festival reflects people's need to enjoy life and pursue health, the Lantern Festival satisfies the pursuit for carnival and celebration. The rapid advance of globalization, information technology and the fast development of industrialization and urbanization, to a considerable extent have changed the way people live, "some of folk symbols or rituals in the traditional festivals have been prohibited, and warmth and vitality in these festivals are gradually disappearing" (Liu et al., 2005). It has been difficult for people to experience the kinship, affection or happy festive atmosphere.

In addition, in recent years, the Spring Festival, Tomb Sweeping Festival, Dragon Boat Festival, and Mid-Autumn Festival gradually have been designated as national legal holidays, ensuring that people have time to celebrate the festivals and experiencing the culture, while the policy also seems to cause more unexpected troubles, like overloading in traffics, services, and travelling facilities. In this way, people grumble about the difficulties in going hometowns, travelling becomes an expensive and depressed activity, and the choices for holidays seem to be small. The negative effects brought by holidays become increasingly prominent, making more and more people begin to re-examine how to adjust in order to highlight the people-oriented holiday philosophy.

\section{Loss of Emotional Experience Identity}

How cohesive a nation or country is depends on whether it has enough emotional identity. It can be said that emotional identity is set of priceless treasure for a community. During the thousands of years' heritance of the Chinese national civilization, traditional festivals have deeply integrated into the emotional world of Chinese people, with strong national sentiment. However, Chinese traditional festivals can no longer reproduce the same national collective emotional experience, although they appear at a specific time each year. Sense of identity has been lost to a certain degree, which is mainly reflected in three aspects.

First, the young generation lacks emotional cognition for traditional festivals. Chinese traditional festivals are now gradually descended into the memory of older people. An increasing number of young people do not know anything about traditional festivals, instead, very familiar with foreign festivals. "After the reform and opening policy, western cultural patterns develop at an unprecedented rate in China. There is no doubt that they have changed the lifestyle and way of thinking of Chinese, especially young people. The concern is that young people is missing traditional festival culture and losing traditional ideals and beliefs when following the so-called western fashion" (Zhang \& Huang, 2005). There are two main manifestations for the lack of emotional cognition for traditional festivals in the young generation. One is that young people cannot fully understand the cultural connotation of traditional festivals. On one hand, their understanding is superficial and abstract. College students today have various ways to learn culture of traditional festivals and most of them do have enthusiasm to learn the culture. But the problem is that they always take a way which is not only inefficient but also is likely to falling into misunderstanding the significance of festival culture. In the current education system of China, learning without reading the classic works is nothing but superficial, leading to incorrectly or partially understanding the culture of Chinese traditional festivals. On the other hand, their understanding is passive and mechanized. Chinese traditional festivals are the significant part of Chinese traditional culture. However, college students today mechanically recite some knowledge of traditional culture just for examinations. They do not autonomously learn more about the profound connotations of traditional culture because of restriction of the examination syllabus $(\mathrm{Li}, 2010)$. The other one is that young people have little experience in celebrating traditional festivals. Their enthusiasm for foreign festivals is far more than that for traditional festivals. For 
example, young people pay much more attention on western Valentine's Day than on Qixi Day. Gifts like roses and chocolates are usually essential for this holiday. Even there are some young people want to celebrate Qixi Day, it is easy for them to mistake roses for the symbol of the Qixi Day. With the fading away of traditional festivals and folk activities, only some old people are keen on their local festivals, while young people just follow the old and even do not know exactly what other customs are included in these festivals. They never have enjoyed the dragons or lions dancing or rowing dragon boats, neither do they know anything about plants like wormwood, calamus or cornel.

Second, ordinary people are lack of enthusiasm for traditional festivals. Chinese traditional festivals are the blood that sustains the development of Chinese national culture, in which ordinary people are regarded as the live cells. Their attention and enthusiasm for traditional festivals are impetus to drive these festivals move forward in the long river of history. However, there is a current trend that the expectation of ordinary people for traditional festivals is obviously not as high as before. In fact, their enthusiasm for participating in festivals is waning. Feng Jicai, a folklorist of China in the ninth cross-strait seminar on Chinese traditional culture and modernization, has said that although there are various cultural festivals held in many places, ordinary people do not really take part in them. But it needs the power of whole people to inherit traditional festivals (2011). Ways of celebrating festivals from agricultural society are difficult to meet modern people's needs for social life because of great changes in modern lifestyle. In Mid-autumn Festival, many people living in urban areas cannot watch the moon due to the soaring skyscrapers; in Dragon Boat Festival, many people do not hang wormwood or watch dragon boats; few people know how to make festival food such as dumplings, rice puddings, glue puddings, year cake or moon cake. Some folklorists even say that nowadays many people's ideas of celebrating festivals only come from the "reminder" of merchants. There are many people each year who get the idea through food for festivals in the markets, like cooking dumplings in Lantern Festival, eating rice dumplings in Dragon Boat Festival and buying moon cakes as gifts for others in Mid-autumn Festival. In this time, merchants get huge profits, but the connotation of festivals is increasing diminishing and people's enthusiasm for festivals is also waning with days. Festivals are almost in name only ( $\mathrm{Su}, 2007)$. In some major traditional festivals such as the Spring Festival, the Dragon Boat Festival and the Mid-autumn Festival, only parents are busy with preparing meals to make celebration and they even have to request their daughters and sons to come back to have a reunion. There is no doubt that people don't have much expectation and enthusiasm for traditional festivals as before.

Third, experts and scholars have increasing concern on the obsolete of traditional festivals culture. In recent years, many Chinese scholars are worried about the waning of traditional festivals. There are some scholars calling for "correcting name" for the Spring Festival. For example, Li Hanqiu, the head of Festival Committee of the Chinese Folk Literature and Art Association, calls for renaming the traditional New Year to "Chinese Year" or "Lunar New Year". There are also some scholars calling that traditional festivals should be applied to join the World Heritage. Take Feng Jicai for example, he suggests putting the Spring Festival in the first place on the list of application for joining the World Heritage. In a certain sense, scholars' calling for renaming traditional festivals and applying traditional festivals to join the World Heritage are due to their anxiety on waning of traditional festivals, which implies the urgent need for protecting traditional festivals and unearthing new cultural connotation of festivals. In 2005, the Dragon Boat Festival declared by Korea was formally identified as "the Oral and Intangible Heritage of Human" by UNESCO. Thus, the Dragon Boat Festival originated from China successfully joined the World Heritage by the application of neighboring country. There was a public outcry in domestic academic circles when this happened. After the depth analysis of scholars, it finally was found that the Dragon Boat Festival of Korea which was originally from China represented unique cultural connotation of Korea with the joint effect of both society and history. This unique culture is reflected in many folk activities such as worshiping by witchcraft, chess matches, taekwondo competition and temple fair in the Dragon Boat Festival. What's worth mentioning is that these customs have been well preserved and spread by the South Korean government who vigorously publicizes these customs and strengthens legislation to protect and inherit them. On the contrary, the Dragon Boat Festival in China has been jokingly named "Rice Pudding's Day" (Zong $\mathrm{Zi}$ Jie), suffering from desert or indifference of ordinary people. This event has profoundly reminded Chinese people of attaching importance to protecting traditional culture in order to avoid losing Chinese cultural identity in the era of globalization.

\section{Missing of Traditional Folk Arts}

Chinese traditional festival is a comprehensive cultural carrier. A variety of folk activities like pasting New Year paintings in the Spring Festival, enjoying lions dance or dragons dance in the Lantern Festival, flying kites in the Tomb Sweeping Festival, racing dragon boats in the Dragon Boat Festival and pinning in the Qixi Day have 
played an important role in the inheritance of traditional folk arts including painting, crafts and costume art. With the full impact of the wave of globalization and informatization, China has been wrecked into the modern world order which has witnessed profound changes in economic system, social structure, patterns of interests and ideological notions. In contemporary society with comprehensive transformation, traditional festivals and folk arts are facing with dilemma of difficult inheritance, which are manifested in two aspects.

The first one is that environment for developing these artistries is increasingly narrow. Customs in traditional festivals have evolved with the development of productive forces, progress of the times, inventions of science and technology and changes in mode of production. Many folk activities affiliated into the festivals have been eliminated or abandoned wholly or partly and the folk arts attached to them are naturally gone because of no demand (Wang et al., 2013). Social demand is the lifeblood of traditional folk arts, while in modern industrialized society where mechanized production has replaced the manual production and become the primary mode of production, "standardized goods produced by machines enter into the markets in large quantities and become popular among people for they are inexpensive, convenient and durable, while traditional handicrafts can hardly meet material needs of people who are in fast-paced lifestyle because their production are time-consuming, inefficient and of high cost. Due to the lack of competitiveness, traditional handicrafts gradually disappear in people's daily lives" (Cao \& Cui, 2008). Now, these traditional folk arts are moving away from people's lives, mothballed in collection, or partly kept by a few artisans inheriting ancient artistry to be appreciated occasionally. Their practical functions are greatly undermined. Thus, many folk arts in traditional festivals are inevitably to fade away.

The second one is that inheritance of artistry is confronted with extinction of artisans and their artistry. Folk arts are usually inherited by imparting from family, learning from teachers, serving as apprentice with skills, introducing to the master by friends, changing from amateur to professional artisans or self-learning $(\mathrm{Ni}, 2005)$. Like many other traditional folk crafts, folk arts in Chinese traditional festivals are facing with problems of interrupted inheritance and no inheritors to varying degrees because of strict requirements of production, sophisticated skills and complicated procedures. Take handmade dragon boats in the Dragon Boat Festival for example. According to the introduction of Feng Huainv who is the representative inheritor of national non-heritage, in artistry of making dragon boats, each step of making dragon boats is very critical, one step closely linked with another. The most critical thing is selecting good timber. That means timber should be perfectly straight, light and long, which is beneficial to control the direction of the boat. After good timber has been selected, it should be very patient and careful in each following procedure of hand making, getting out of water (bent the keel and make it streamline), making it level (locate keel in midline), changing the direction of water (install baffle), making big boat sides (install boat sides), making crosspiece and sitting board, installing dragon intestine, strengthening midgut (fix seats and intestine by bamboo), coating ash of tung oil (fill crevices between boards to avoid water leakage), planning, polishing and coloring. No minor error is allowed in these procedures. Dragon boats making in this way can be streamline and will have less resistance in water (2012). "Heritage of Chinese folk culture normally exists in memory and artistry of inheritors. However, artisans usually scatter in rural areas. Most of them are old and have no inheritors. The phenomenon that artistry disappears with the death of artisans is quite common" (Zhang, 2006).

\section{The mess of Application of Festival Symbols}

Chinese traditional festival is a system consisting of various symbols. "The traditional festival symbol system is mainly composed by the time symbol systems, space symbol system, ritual symbol system, music and dance system, mascot symbol systems, language and literature symbol system, numeric symbol systems, apparel symbol system, food offerings symbol system and entertainment system" (Dong, 2008). By virtue of these cultural symbols, modern Chinese can regularly master and comprehend the cultural heritages in the traditional festivals which exist for more than thousands of years. However, there is some mess in the application of these systems as following three aspects.

First, festival date - days for spending the festivals, counted by the lunar calendar is easily concealed by the Gregorian calendar. In all the symbolic systems, festival date is the most directly grasped numerical symbol, and also the first to enter people's vision, so master of the date is the basic reason for the flourishing of one specific festival. In Chinese history, after the great revolution of 1911 took place, China officially adopted the Gregorian calendar, instead of using the traditional Chinese calendar - lunar calendar, thereby producing inconvenience for traditional festivals because of the inconformity of the two calendars. As some scholars have pointed out, "during the revolution, at the time to say farewell with traditional society, some things do not quite properly, such as the use of pure Gregorian calendar, abolishing the old calendar, and the festivals attached to the traditional calendar were also destroyed" (Xiao, 2009). Since 1912 starting to adopt the Gregorian calendar, all 
the living and working time of Chinese people follow the Gregorian calendar, but the Chinese traditional festival mostly follow the lunar calendar, which need to be translated into lunar dates, causing the festival date is not fixed but in constant change. Thereby, this results in confusion for people especially young generation about the festival dates, and for them, if there is no reminder from the media, the festival dates followed the lunar calendar can easily been forgotten.

Meanwhile, conflict between the time values for the traditional festivals and modern times can easily made the festival date being concealed. Division for the Chinese traditional festivals come from the Chinese people's time experience and time intuition, possessing characteristics like periodicity, heterogeneity, reversibility and specificity, which can be seen the way and rhythm ancient people get along with the universe, the earth and the people themselves, reflecting the accommodation between the human being and the natural principle. In comparison, the time value in modern society is linear, homogeneous, abstract, has evacuated the substantive content of traditional festivals time. The celebration, rituals, clothing and other features of the festival time have just served as the "embellishment" of the modern time (Hu, 2010). It can be seen that there is some conflict between the two times, which makes the time in traditional festivals easy to be concealed by the modern time, slipping out of the memory of the population, causing the irreconcilable contradiction between them.

Secondly, the inconformity of the festival activities to the themes. Themes are the direct products of festival culture, the unique connotations and ideology owned by the festivals. It is very crucial that the activities should be closely related to the core culture value (Zhou, 2009). However, there is common phenomenon that the activities do not correspond to the themes in current Chinese traditional festivals. For example, some theme activities like patriotism education in Dragon Boat Festival have been grafted into Tomb Sweeping Festival, on which many schools will organize students to mourn the Martyrs, Heroes Monument, Celebrities, etc. Obviously, the function of Dragon Boat Festival in patriotism has weakened.

Another example is the Qixi Day, also called Chinese Valentine's Day, which is a product in Chinese agricultural society. Ancient woman in the Qixi Day will watch the moon to beg for pair of skillful hands and a good craft. However, nowadays, on this day, shopping malls will launch a lot of promotional activities, employing flowers, chocolates, food dinners, movies or other forms of activities in order to create a romantic atmosphere to attract consumers, which is a blunt imitation and copy from the western Valentine's Day, deviated from the original theme of Qixi Day. Apart from these, in fact, the same problem also exists in Mid-Autumn Festival, Double Ninth Day and other traditional festivals to different extent.

Third, over business operations of festival food, mascots and other physical symbols. A series of uncivilized behaviors emerged in the commercial operation of current Chinese traditional festivals. Year after year, high-priced moon cakes or rice puddings frequently appeared in consumer market have been criticized. In 2004, one shopping mall in Beijing produced a golden moon cake with heavy of 110 kilogram and price of 9,999 RMB, and also in 2013 one restaurant in Taiyuan city produced another rice pudding made of truffle, abalone and Thai fragrant rice with a price of 9,999 RMB. These products wrapped in the cloak of commercial gimmick and catered to some bad social atmosphere, seriously violating the original intention for inheriting the traditional festivals. What's more, frequently festival food safety issue is also questioned. In 2001, news of the expiring filling in the moon cake made by one store caused the sales of moon cake in that year declined about forty percent. This kind of issue not only led to economic losses, but also a serious impact on the public interest in traditional festivals.

\section{The Popularity of Western Festival Cultures}

In recent years, "some western festivals, such as Christmas, Valentine's Day, April Fool's Day, Halloween, etc. become increasingly popular in China, but Chinese indigenous festivals like the representative of China- the Spring Festival - are in a way left out in the cold, caught by danger of dissolution and marginalization"(Song \& $\mathrm{Ru}, 2012)$. The impacts from the western festival cultures on Chinese traditional festivals are mainly manifested in the following two aspects.

First, blind imitation of local traditional festivals from western festivals. This imitation mainly demonstrated in the festival industry and festival content. For the industry, along with the development of globalization, western festival industry with its strong economic and cultural output has also been introduced to China. "Festival industry is the comprehensive representation of national culture, folk culture, the cultural creation and commercial activities, etc. According to incomplete statistics, there are about eighty thousand renowned festivals in the world, $95 \%$ of which are originated in the developed countries" (Ke, Qi, \& Guan, 2009). The imitation is also reflected in the festival's commercial nature, such as the promotion events in various shopping malls during 
the holidays throughout China, organizing culture theme weeks for the purpose of consumption, the film exhibition at the background of traditional festivals, etc.

From the content view, the most typical imitation is the Qixi Day, According to "Jingchu Chronicle", on the evening of double seven's day, with colorful threads, women practice the seven-hole needle, or make the golden or silver stone as the needles, preparing fruit and melons in the courtyard begging for skills. If there is some $x i z i$ appearing on the melon that means it has corresponded to the begging. This custom has continued in the Republic of China era (Li, Qi, \& Guo, 2005). Obviously, local Qixi Day is very poetic, while now the festival has long been defeated to the western Valentine's Day, the feast contents turned to buy roses, chocolates, watch movies, eat a fancy dinner, etc., losing its unique customs and rich cultural meanings.

Secondly, the western holidays enjoy great popularity among young people. People's attitude to the festivals reflects the emotional identity for the national culture, especially for the young generation as the inheritors of the nation's cultural heritage, their emotional attitude is very crucial to the overall trend of the future development of national culture. The development of China's reform and opening as well as the increasing cultural exchanges have deepened the understanding of western festivals, like Christmas, Mother's Day, Father's Day, April Fool's Day, Valentine's Day and other western festivals, whose freshness, fashion, entertainment and strong festival features have quickly gained currency in contemporary youth group. Western festivals in China have grown from the initial development from the breeze to rain storm, particularly popular and warmly welcome among young people; while Chinese traditional festivals have worsened for the impacts of foreign festivals (Zhao, 2006).

\section{Conclusion}

Chinese traditional festivals are the symbol of traditional Chinese culture, which encountered anomie situation in contemporary society. To some extent, this is a reflection of the traditional culture facing enormous challenges and difficult alternatives during its social transformation to the creative metamorphosis in modern time. For contemporary Chinese people, the deep cultural connotations and values inherent in the traditional festivals may not be fully understood and accepted, but the national memory and sentiment, have been imprinted in every Chinese person's blood for thousands of years, become a collective unconscious for this nation. Although there are some problems in inheriting these festivals in modern society, they are not completely disintegrated, and so it is imperative to reconsider and reconstruct them through restoring their original cultural connotations with new carriers and forms. Besides, the sophisticated festival culture should be connected with the need of contemporary people, respecting the tradition but also developing it, in order to arouse the common national memory and culture awareness. Traditional festivals should get back in people's daily life, exerting its functional role in maintaining national solidarity, enhancing cohesion and increase national identity. Facing the globalization, the traditional festivals should go forward to the renaissance from obsolete.

\section{Acknowledgments}

This work was supported by the General Project of National Social Science Funding of China (Project no. 11BSH037) and 2013 Chongqing Art Science Planning Youth Program (13DH020).

\section{References}

Cao, Q. Z., \& Cui, S. J. (2008). Shallow Theory of Protection and Development of Traditional Folk Crafts. Journal of Jiangxi Science \& Technology Normal University, 2, 113.

Traditional Festival Custom also should Keep Pace with the Times. (2011, April 7). Chinese Culture Media Network.

Dong, J. Q. (2008). Symbolized Survival of Traditional Festivals and Cultural Soft Power. Chongqing Social Science, $8,127$.

Durkheim, E. (2000). The Division of Labor in Society. SDX Joint Publishing Company, 4.

Feng, J. C., Xiang, Y. J., \& An, D. M. (2009, April 10). Dig Traditional Festivals Resources and Inherit National Culture. Chinese Arts Report.

Hu, X. H. (2010). Chinese Traditional Festivals and Modernistic Concept of Time. Anhui University Journal, 3, 53-58.

Ke, H. L., Qi, S. H., \& Guan, Z. C. (2009). Enlightenment of Western Festival Industry to China. City Observation, 3, 79-80. 
Li, M. (2010). Contemporary College Students Understanding about the Characteristics of Chinese Traditional Culture. Culture in Contemprorary Enterprise, 5, 89.

Li, S. B., Qi, L. H., \& Guo, Y. M. (2005). Festivals and Celebration. Chinese Literature and History Press, 1.

Li, Z. H. (2008). Practical Rationality and Musicality culture. SDX Joint Publishing Company, 6.

Liu, K. L., Xiao, F., Zhang, B., Liu, X. F., \& Zhou, X. (2005). Traditional Festivals and Contemporary Society. Folk Culture Forum, 3, 4.

Liu, Y. X. (2007, September 18 ). Experts are Calling for Restoring the Face of Mid-Autumn Festival Culture and Moon Cakes. Economy Reference.

Zhao, H. (2006). The Game between Chinese Traditional Festivals and Western Festivals. News World, 6, 272.

Ni, Z. Z. (2005). General Annals of Chinese Folk Custom: Acting. Shandong Education Press, 12.

Traditional Festivals: The Cultural Memory that should not Vanishe. (2011, January 31). Guang Ming Daily.

Talk about Dragon Boat in Dragon Boat Festival in the Year of Dragon. (2012, June 22). Gung Ming Daily.

Song, J. L., \& Ru, X. (2012). An Investigation and Suggestion of the Foreign Traditional Festival Essence. Hundred Schools of Arts, 5, 56.

Su, Z. F. (2007, March 23). Fall on the Edge of Traditional Festivals: Reformed in the Change. Quanzhou Evening.

Wang, J. X., Duan, W. J., Wang, Z. Z., Guo, D. R., Tang, X. Q., \& Wang, C. P. (2013). The Analysis of Historical Evolution and Contemporary Value of the National Tradition Festivals. Journal of Hubei Institute for Nationalities (Philosophy and Social Sciences), 2, 3.

Xiao, F. (2009). Unearth and Use the Resource of Chinese Traditional Festivals. N.W.Ethno-National Studies, 2, 148.

Yu, H. G. (2012). Modern Inheritance of Chinese Traditional Festivals. Journal of Shenyang Normal University (Social Sciences Edition), 4, 88.

Zhang, H. W., \& Huang, B. L. (2005). The Meaning of Protecting the Traditional Festival Culture. Tribune of Social Sciences, 5, 51.

Zhang, J. H. (2006, August 7). Guangdong: Let Folk Art to Continue with the Family Line. Guang Ming Daily.

Zhou, J. (2009). Hierarchical Guidance Strategy for the Festival Theme Activities. Journal of Educational Development, 7, 29-31.

\section{Copyrights}

Copyright for this article is retained by the author(s), with first publication rights granted to the journal.

This is an open-access article distributed under the terms and conditions of the Creative Commons Attribution license (http://creativecommons.org/licenses/by/3.0/). 